Acewicz M., Promocja regionu przez inwestycje zagraniczne, „Ekonomia i Prawo”, Polszakiewicz B., Boehlke J. (red.), Tom XII, nr 1/2013, ss. 115-126 DOI: http://dx.doi.org/10.12775/ EiP.2013.010

\title{
PROMOCJA REGIONU PRZEZ INWESTYCJE ZAGRANICZNE
}

\section{STRESZCZENIE}

Globalizacyjne scalanie świata zwykle rozpoczyna się od gospodarczych powiązań kapitałowo-produkcyjnych. Ulokowanie się w poszczególnych regionach nieintencyjnym. Samopromocja tylko przez sam fakt zaistnienia czegoś $\mathrm{w}$ jakimś otoczeniu realizuje się $\mathrm{w}$ wymiarze identity $i$ image. Identity promocji to tożsamość regionu w kontekście zmian jego potencjału gospodarczego i społecznego, image to postrzegana wizytówka zamożności i sukcesu całego terytorium jako szansa i skutek regionalnych inwestycji.

Słowa kluczowe: samopromocja, wizerunek, inwestycje zagraniczne

Klasyfikacja JEL: A13, R11, R52

\section{PROMOTION OF THE REGION BY FOREIGN INVESTMENT}

\section{SUMMARY}

Globalization of the world usually starts with the economic, capital and production relations. Locating foreign investment in different regions starts their promotion.

* Mirosław Acewicz, Politechnika Białostocka, Wydział Zarządzania, Katedra Ekonomii i Nauk Społecznych, ul. Ojca Tarasiuka 2, 16-001 Kleosin, e-mail: m.ace@vp.pl. 
Self-promotion just by the sheer existence of something in a certain environment is implemented identity and image dimensions. Promotion identity is the identity of the region in the context of changes of its economic and social potential, whereas an image is a visible sign of wealth and the success of the entire territory perceived as a chance for, and at the same time, the result of regional investments.

Keywords: self-promotion, image, regional investments

JEL Classification: A13, R11, R52

\section{WSTĘP}

Postępujący proces integracji polskiej gospodarki ze strukturami gospodarczymi świata obecnie jest już zauważalny nawet w regionach, dotąd zapóźnionych w rozwoju swoich możliwości gospodarczych i technologicznych. Proces ów, wyjściowo zależąc od wielu czynników, dokonuje się głównie poprzez coraz silniejsze powiązania kapitałowo-produkcyjne i różnorodne formy inwestycji zagranicznych, przez środki finansowe, rzeczowe aktywa trwałe, wartości prawne czy bezpośrednie inwestycji zagraniczne ${ }^{1}$. Towarzyszą mu, odnotowywane powszechnie, konsekwencje. Jako dodatnie skutki napływu kapitału zagranicznego występują: rozwinięcie asortymentu i technologii produkcyjnych, upowszechnienie nowoczesnego managementu, wzrost wydajności pracy i produkcji czy nowe miejsca pracy. Wraz z samą inwestycją zagraniczną stają się samonapędzającym się mechanizmem nie tylko gospodarczym, ale i promocyjnym dla siebie i dla otoczenia, szczególnie w sytuacji braku zdecydowanej polityki kreowania przyjaznego środowiska dla prowadzeniu biznesu. Celem niniejszego opracowania jest diagnoza i ocena sytuacji, w której przy stosunkowo niskiej efektywności promocji inwestycji zagranicznych w wymiarze regionów zacofanych gospodarczo, nadto peryferyjnych jak Podlasie i Białystok, lokowane w nich inwestycje zagraniczne generują nieintencyjny efekt promocyjny przez sam fakt zaistnienia rynkowego.

\section{EFEKT TOŻSAMOŚCI I WIZERUNKU PROMOCJI RYNKOWEJ}

Obecnie warunkiem sukcesu gospodarczego jest poprawnie realizowany proces komunikacji rynkowej, w której informacja zarazem zachęca, wręcz na-

${ }^{1}$ J. Witkowska, Ekspertyza dla Ministerstwa Rozwoju Regionalnego: Rola kapitatu zagranicznego w kreowaniu przewag konkurencyjnych polskiej gospodarki, Łódź 2009, s. 11. 
kłania, co jest istotą pojęcia promocji i promocji jako działania celowego ${ }^{2}$. Efektywność wykorzystanej w danej akcji promocyjnej perswazyjności komunikatu zależy od praktycznie nieskończonego spektrum warunków charakterystycznych dla danego czasu i przestrzeni, co powoduje, że ewentualny sukces staje się niewymierny bezpośrednio, a jako odłożony w czasie obarczony jest nadto niepewnością. Promocja jednak, szczególnie w odniesieniu do wszelkiego rodzaju inwestycji, ma także wymiar nieintencyjny. Pojawia się bowiem już przez sam fakt zaistnienia czegoś w jakimś otoczeniu, jeżeli owo coś dysponuje cechami wyróżniającymi i informacyjnie jest uświadamiane przez odbiorcę.

$\mathrm{Na}$ poziomie myślenia i towarzyszącej temu praktyki, promocją oznaczano wszelkiego typu zabiegi zwiększania popularności czegoś lub kogoś, zarówno w wymiarze rozprzestrzeniania się poziomego przez zajmowanie jakby coraz większej powierzchni, jak i pionowego jako zmierzania do pozycji najlepszego w jakiejś skali ${ }^{3}$. Przekładało się to na specyficzne działania lansowania przez upowszechnianie. $Z$ czasem promocja stała się zespołem precyzyjnych czynności podporząakowanych świadomości zakładanych celów i osiąganych efektów na poziomie rynkowym. Do ich zrealizowania potrzebne są nie tylko środki finansowe, ale i umiejętności w doborze różnorodnych treści i form ich ujawniania medialnego. Wykorzystując marketingowo rozpoznane prawidłowości i używając odpowiedniego zestawu instrumentów promocyjnych aktywizuje się sprzedaż w długim lub krótkim okresie i w konsekwencji proces zwiększenia udziału w rynku.

Mechanizm promocji rynkowej nastawiony jest na kształtowanie sposobu myślenia otoczenia, którego fizyczną podstawą są elementy identyfikujące, a celem mentalne wyobrażenie pod postacią wizerunku. W ramach kreacji tożsamości i wizerunku promowany przedmiot, $\mathrm{z}$ jednej strony funkcjonuje $\mathrm{w}$ postaci diagnozowanych elementów jego struktury, z drugiej w formie umysłowej jako świadomość szeregu doświadczeń jego odbiorcy. W skali gospodarki, promocja przez tożsamość i wizerunek, w jednym i drugim przypad$\mathrm{ku}$, dotyczy swoistej wiedzy praktycznie stosowanych zabiegów w odniesieniu do rygoryzmu możliwych do zaplanowania działań, szacowanej ich wartości w przyszłości oraz zewnętrznych kontekstów ewentualnego sukcesu. Podstawowym i długofalowym celem takich działań promocyjnych jest wytworzenie w odbiorcach pożądanej świadomości marki na rynku. Dokonuje się to przez wpływ bezpośredni i pośredni, na bazie różnorakich opisów ujawnianych faktów, jak również poprzez modyfikację myślenia o nich przez ich potencjal-

${ }^{2}$ W. J. Wiktor, Promocja. System komunikacji przedsiębiorstwa z rynkiem, Warszawa 2001, s. $43-49$.

3 Zob. Stownik jezyka polskiego PWN, t. 3, Warszawa 1999, s. 894-895. 
nych oraz realnych odbiorców. Proces ten odwołując się do realnych dokonań i podkreślania uchwytnych fizycznie cech swojej tożsamości, jest więc zarazem tworzeniem wizerunku.

Tożsamość jest sumą elementów wyróżniających z otoczenia. W praktyce promocji są one kodowane różnorodnie i w szerokim zakresie, od samego faktu zaistnienia rynkowego, przez szereg różnorodnych sposobów transmisji tej informacji do otoczenia, łącznie $\mathrm{z}$ wyrafinowanymi strategiami i technikami wspomagania procesu realizacji samych aktów realnych kontaktów z odbiorcą. Elementem dynamiki zjawisk tożsamościowych jest wizerunek. Jego punktem wyjścia są zawsze zmysłowo doświadczane tożsamościowe elementy identyfikujące i wyróżniające ${ }^{4}$ na etapie ich kontaktu $\mathrm{z}$ grupami otoczenia, jako pracownikami, klientami czy społecznościami. Z czasem wizerunek zaczyna funkcjonować jako odróżnialna od innych reprezentacja umysłowa, zindywidualizowany twór mentalny, ale na bazie zestawu cech diagnozowanych empirycznie. Jeżeli odnosi rynkowy sukces staje się marką, czyli zespołem stosunkowo stałych wskazań czegoś już w skali świadomości społecznej.

Podstawą tożsamości i wizerunku jest wartość użytkowa w relacji do swojego otoczenia. W odniesieniu do produktu zaczyna ona funkcjonować już od momentu jego fizycznego zaistnienia na rynku. Tożsamość i wizerunek produktu bezpośrednio zależą od stopnia zaspokojenia potrzeby potencjalnego nabywcy, pośrednio zaś od funkcjonalności i oceny zewnętrznej formy jako zgodnej z akceptowalnym kanonem wyglądu zewnętrznego ${ }^{5}$. Diagnozowane pozytywnie, automatycznie, bez zamierzonych działań, promują produkt i jego wytwórcę oraz otoczenie, w jakim się pojawia. Podobnie jest w odniesieniu do firm. Sukces rynkowy przedsiębiorstwa na danym terenie skutkuje samoczynnie generowaną promocją samej firmy i regionu, w którym ona funkcjonuje, przy czym silną promocyjnie jest już sama informacja o otwieraniu nowych firm czy napływie kapitału i w konsekwencji atrakcyjności inwestycyjnej danego terenu.

Określanym czasowo i finansowo celem promocji jest sukces rynkowy, mierzony zwiększeniem sprzedaży produktu, ilością nowych inwestycji czy rozpoznawalnością regionu. Cel długoterminowy to stworzenie pozytywnego odbioru promowanego obiektu. Swiadomość celu wydawanych pieniędzy i nawet pewność wyboru takich, a nie innych form promocji nie gwarantuje jednak sukcesu. Zbyt duża liczba zmiennych i niejednoznaczność standardów interpretacji treści promocji oraz osiąganych efektów powoduje, że działania

\footnotetext{
${ }^{4}$ Ph. G. Zimbardo, Psychologia i życie, Warszawa 1999, s. 319.

${ }^{5}$ L. Garbarski, J. Rutkowski, W. Wrzosek, Marketing punkt zwrotny nowoczesnej firmy, Warszawa 1996, s. 238.
} 
takie na poziomie wdrażania i osiągania założonych celów muszą się liczyć nawet $\mathrm{z}$ możliwością porażki. Akcje promocyjne tożsamości i wizerunku, nastawione na ich budowanie i umacnianie, skazane są więc jedynie na postulatywność. W takim kontekście promocja nabiera wartości jako działanie nieintencyjne. Jeżeli sukces rynkowy, produktu, firmy czy regionu, staje się faktem, informacja o tym, ubocznie i mimowolnie, zaczyna pełnić funkcję nie tylko komunikacyjną, ale i perswazyjną. Przekazuje treść zachęcając, czyli promuje. Jest to wprawdzie proces nieprzewidywalny i jako rozciągnięty w czasie, niepoddający się bezpośredniej ocenie, ale nie wymaga on celowego angażowania środków finansowych i jest przyjazny w odbiorze. Promocji klasycznej bowiem, jako działaniu o charakterze informacyjno-wspierającym, promocja nieintencyjna odbiera aspekt zamierzonego przekonywania i redukuje ją do jakby czystej informacji, co z dużym prawdopodobieństwem ma szansę na powszechną akceptację odbiorcy.

\section{KAPITAŁ I INWESTYCJE ZAGRANICZNE NA PODLASIU I W BIAŁYMSTOKU}

Promocyjny efekt tożsamości w odniesieniu do regionalnych inwestycji definiuje już sam fakt ich zaistnienia. W latach 2005-2010 w województwie podlaskim powstały 82 firmy, których właścicielami lub współwłaścicielami są cudzoziemcy. W samym Białymstoku w roku 2008 zarejestrowanych było 249 spółek handlowych z udziałem kapitału zagranicznego, w tym 107 z wyłącznym kapitałem zagranicznym. Firmy zagraniczne lokując się w regionie, doceniły jego atrakcyjność inwestycyjną, jego potencjał gospodarczy, intensywny rozwój i niskie koszty prowadzenia firmy ${ }^{6}$. Ich identyfikowana i wyróżniająca je $\mathrm{z}$ otoczenia tożsamość, wsparta uznaną renomą, pracuje zarazem promocyjnie dla województwa, stając się istotnym elementem wizytówki całego regionu. Dzieje się tak dlatego, że element obcy w środowisku automatycznie i samoczynnie przyciąga i kondensuje uwagę, zarówno na siebie jak i na swoje bezpośrednie otoczenie. Kapitał i inwestycja zagraniczna w regionie są natychmiast rozpoznawalne i poddawane, zazwyczaj pozytywnej ocenie, chociażby za odwagę podjęcia ryzyka. Staje się on nadto podstawą wnioskowania o atrakcyjności terytorium i regionu jako umożliwiających tego typu projekty gospodarcze ${ }^{7}$.

\footnotetext{
${ }^{6}$ www.podlaskie.strefabiznesu.pl, stan z dnia 4.05.2012.

${ }^{7}$ H. Godlewska-Majkowska, P. Zarębski, Atrakcyjnośc inwestycyjna regionów 2010. Wojerwództwo podlaskie, Warszawa 2010, s. 3.
} 
Spektakularną dla Podlasia inwestycją 2010 roku stała się budowa fabryki Ikei ${ }^{8}$. Należy ona do szwedzkiego koncernu ze spółką w Polsce „Swedspan Polska Sp. z o. o.” Po zakończeniu planowanych etapów inwestycji, do 2015 roku, ma tam pracować dwa tysiące osób, co radykalnie zmienia, wręcz rozwiązuje, problem bezrobocia $\mathrm{w}$ tym regionie. Pierwszy etap działalności to wytwarzanie ultra cienkich płyt HDF do produkcji mebli, w dalszych nawet stworzenie własnego tartaku w ramach inwestycji o wartości $627,2 \mathrm{mln}$ zł. (145,7 mln zł pochodzi z unijnego programu Innowacyjna Gospodarka) 9 . Fabryka ta, jako najnowocześniejszy zakład tego typu w Europie, stała się powszechnie uświadamianym argumentem, że Podlasie to nie tylko turystyka, ale też miejsce gospodarczego angażowania kapitału i awansu cywilizacyjnego. Pracują na to też inwestycje powstałe wcześniej. Już od kilku lat pierwsze miejsce w Złotej Setce Podlasia pod względem przychodów zajmuje augustowska część grupy British American Tobacco, sprzedającej swoje produkty na ponad 180 rynkach całego świata ${ }^{10}$. Firma rozpoczęła działalność w 1991 roku i obecnie zatrudniając ponad 750 osób produkuje rocznie ok. 36 miliardów sztuk papierosów do około 50 krajów. Ciągłe inwestycje w obiekty i linie technologiczne przysporzyły jej miano jednej z najnowocześniejszych fabryk w Unii Europejskiej. Bardzo ważną rolę na rynku podlaskim odgrywa firma Pfleiderer Grajewo S.A. Przy zatrudnieniu około 500 osób zdolności produkcyjne spółki wynoszą ok. $670.000 \mathrm{~m}^{3}$ płyt rocznie. Blisko 100\% sprzedaży kierowane jest do branży meblarskiej, z czego znaczną część produkcji eksportuje się głównie na rynki wschodnie. W 2012 roku firma w ramach programu modernizacji zamierza zainwestować w grajewski zakład 20 milionów zł.

Północno-wschodnim centrum gospodarczym Polski o największej liczbie przedsiębiorstw z kapitałem zagranicznym jest Białystok. W roku 2008 zarejestrowanych było 249 spółek z udziałem kapitału zagranicznego, z czego 107 z wyłącznym kapitałem zagranicznym. Firmy zagraniczne o uznanej renomie to Bianor (Boog B.V.), Leroy Merlin (Groupe Adeo), Castorama (Grupa Kingfisher), Inditex (grupa z kapitałem hiszpańskim), Polpled, Philips, Kompania Piwowarska czy Polmos ${ }^{11}$. Bianor na przykład jest liderem na rynku przetwórstwa tworzyw sztucznych. Zatrudnia około 320 osób, organizując pracę w systemie 4-zmianowym, co zapewnia produkcję $24 \mathrm{~h}$ na do-

${ }^{8}$ Wielkość i innowacyjność inwestycji Ikei w Polsce to jedna trzecia jej produkcji oraz 10 tys. bezpośrednich miejsc pracy (40 tys. pośrednich) - dane z wypowiedzi Premiera Donalda Tuska. Zob. www.bialystok.gazeta.pl, stan z dnia 15.06.2011.

${ }^{9}$ www.wspolczesna.pl, stan $\mathrm{z}$ dnia 15.06.2011.

${ }^{10}$ www.bat.com.pl, stan z dnia 4.05.2012.

11 Lista najwięekszych inwestorów zagranicznych w Polsce - grudzień 2011 wg PAIiIZ S.A. 
bę przez 7 dni w tygodniu. Aktualnie inwestuje w budowę nowych hal produkcyjnych, całkowite koszty szacuje się na ponad $16 \mathrm{mln}$ zł. Firma Leroy Merlin z kolei to drugi w Europie i czwarty na świecie dystrybutor w branży budowlanej. Swoją pozycję gospodarczą i renomę buduje od roku 1923. W Polsce firma Leroy Merlin rozpoczęła działalność w 1994 roku i w 2012 roku posiadała 43 sklepy w dużych i średnich miastach, o powierzchni handlowej od 6,0 do 18 tysięcy $\mathrm{m}^{2}$. W projekty centrów handlowych, w latach 2007-2008, zainwestowali w Białymstoku ponadto JWK Group, Meinl European Land Group czy Spirit International. Galeria Biała na przykład, aktualnie CH Atrium Biała, należy do Spółki Atrium Poland Real Estate Management $\mathrm{z}$ kapitałem amerykańsko-izraelskim i zarządza obecnie 20 centrami w Polsce.

Podlasie i Białystok z firmami z kapitałem zagranicznym to postępująca zmiana statusu ekonomicznego regionu i zarazem jego naturalna promocja. Decyzje inwestycyjne spoza Polski powodują, że teren województwa staje się równoprawną technologicznie i rozpoznawalną częścią rynku globalnego. Dzięki inwestycjom zagranicznym i wpływom z podatków i opłat do budżetu Podlasie i Białystok przy stopie bezrobocia 12,6\% (na koniec czerwca 2011) może liczyć na poprawę tej sytuacji z jednej strony, z drugiej jest w stanie przeznaczać większe środki finansowe na realizację celów regionu i miasta. Teren województwa staje się w konsekwencji coraz bardziej atrakcyjnym regionem dla inwestorów zagranicznych, postrzeganym jako dynamicznie się rozwijający, przyjazny inwestorom oraz interesujący pod względem społecznym.

\section{SKUTKI NAPŁYWU INWESTYCJI ZAGRANICZNYCH}

Wizerunek jest mentalnym obrazem kogoś lub czegoś, jest tym, co ludzie o tym myślą. Na promocyjny efekt image w układzie regionalnych inwestycji zagranicznych składa się wyjściowo i przede wszystkim percepcja ich bezpośrednich skutków, w dalszym planie zaś świadomość ich znaczenia gospodarczego i społecznego dla danego regionu. Wizerunek ukształtowany to promocyjna wizytówka nie tylko samej firmy zagranicznej, ale i jej bezpośredniego otoczenia. Analiza rynku podlaskiego i białostockiego pokazuje, że napływ kapitału i inwestycji zagranicznych to szansa rozwoju gospodarczego i społecznego. Firmy obcokrajowe, inwestujące szczególnie od podstaw (greenfield), to z reguły struktury innowacyjne technologicznie na poziomie światowym. Bezpośrednio wpływają na rynek pracy i zatrudnienia, a wnosząc zasoby finansowe podnoszą wyjściowy status zamożności. 
Wpływ kapitału zagranicznego jest zawsze wielowymiarowy ${ }^{12}$. Bezpośrednio skutkuje to wzrostem możliwości i nakładów inwestycyjnych, wprowadzaniem innowacyjnych technologii, powstawaniem produktów o nowym profilu, pojawia się też $\mathrm{z}$ reguły wzorzec innego zarządzania firmą. Pośrednio konkurencyjność i kooperacja $z$ firmami krajowymi wyzwala efekt naśladownictwa ${ }^{13}$. Przedsiębiorstwa starają się dorównać na nowo określonemu poziomowi ilości i jakości w zakresie produkowanego asortymentu, przejmują również pojawiające się sposoby efektywnego zarządzania i marketingu. Tak kształtujące się pozytywne trendy napływu kapitału zagranicznego odnotowano w Polsce i na Podlasiu ${ }^{14}$. Dominujące sposoby powstawania spółek z udziałem zagranicznym to albo wspólne przedsięwzięcie inwestora zagranicznego z partnerem polskim, albo tworzenie przez inwestora zagranicznego przedsiębiorstwa z jego 100\% udziałem. W ogólnej liczbie przedsięwzięć tego typu przede wszystkim jednak dał się zauważyć rosnący odsetek inwestycji greenfield. Już w 2008 roku do Polski trafiły 353 projekty o łącznej wartości 34 mld dolarów w całym okresie trwania inwestycji ${ }^{15}$.

Pozytywny wpływ kapitału zagranicznego na rozwój kraju i regionów ujawnił się stosunkowo szybko przede wszystkim w odniesieniu do rynku pracy i modernizacji gospodarki. Liczba pracujących w spółkach z udziałem kapitału zagranicznego już na koniec 2008 roku wynosiła 1.532 tys. osób ${ }^{16}$. W 2009 r. w związku $\mathrm{z}$ wieloletnimi programami wsparcia powstało ok. 24 tys. nowych miejsc pracy, wartość tych przedsięwzięć wyniosła ok. 9 mld zł. W województwie podlaskim liczba nowych miejsc pracy tworzonych $\mathrm{w}$ związku $\mathrm{z}$ projektami greenfield w 2009 r. wyniosła 4,4\% w skali kraju, zaś pracujących w podmiotach z udziałem kapitału zagranicznego w 2009 r. ogółem było 8915. $Z$ roku na rok kapitał zagraniczny nabiera coraz większego znaczenia. Firmy z jego udziałem już w 2007 roku osiągały średnio prawie 35\% obrotów przedsiębiorstw ogółem, podczas gdy na początku dekady procent ten wynosił $25 \%$. Bardziej szczegółowe dane pokazują, że w wielu rodzajach działalności firmy z kapitałem zagranicznym osiągają udziały w obrotach powyżej 50\%, przy znacznie niższych udziałach $\mathrm{w}$ zatrudnieniu - średnio 23,3\% udziału w zatrudnieniu ogółem. Firmy te ponoszą też coraz większe nakłady inwestycyj-

12 Z. Chrupek, Stan zagranicznych inwestycji bezpośrednich w Polsce, Warszawa 2002, s. 19.

13 B. Liberda, Inwestycje zagraniczne, oszczędności wewnętrzne i polityka gospodarcza, Warszawa 1999, s. 26.

${ }^{14}$ W. Dziemianowicz, Inwestycje zagraniczne jako czynnik rozwoju polskich regionów, Warszawa 2002, s. 11.

${ }^{15}$ www.kancelaria.lex.pl, stan z dnia 4.05.2012.

${ }^{16}$ Działalność gospodarcza spółek z udziałem kapitału zagranicznego w 2008 roku, GUS, listopad 2009. 
ne na środki trwałe brutto, w niektórych dziedzinach gospodarki już w 2007 roku sięga nawet 80-99\%. Wkład inwestorów zagranicznych w modernizację polskiej gospodarki potwierdza także wzrost zatrudniania pracowników badawczych (w 2007 wynosił 44,9\%, co oznaczało skok aż o ponad 40 punktów procentowych $\mathrm{w}$ analogicznym okresie) ${ }^{17}$.

$Z$ inwestycjami zagranicznymi, obok pozytywnych, wiążą się też zjawiska kontrowersyjne czy wręcz negatywne ${ }^{18}$. Efekty niekorzystne napływu kapitału obcego, bezpośrednio ujawniane, to przede wszystkim stosunkowo niska skłonność do reinwestowania zysków i rozwijania w Polsce działalności badawczo-rozwojowej, co radykalnie spowalnia proces rozwoju technologicznego gospodarki kraju. Raczej niewielki udział polskich komponentów w produktach firm zagranicznych i stosunkowo wysoki poziom importu zaopatrzeniowego $\mathrm{w}$ całości importu firm $\mathrm{z}$ udziałem zagranicznym to $\mathrm{z}$ kolei bariery wolnego w efekcie włączania rodzimych przedsiębiorstw w kooperację. Duża presja konkurencji firm zagranicznych powoduje także znaczne osłabienie lub likwidację polskich konkurentów w obszarze wysokich technologii. Widocznym dla przeciętnego obserwatora skutkiem napływu inwestycji zagranicznych jest ponadto omijanie polskiego systemu podatkowego i postępująca $\mathrm{w}$ wyniku procesu urbanizacji przemysłowej dewastacja środowiska.

Powszechnie identyfikowane pozytywne konsekwencje gospodarcze napływu kapitału zagranicznego to kontekst, który pozwala inwestycjom zagranicznym na nieintencyjne generowanie efektu promocyjnego jedynie przez sam fakt zaistnienia rynkowego. Inwestycja zagraniczna jako sukces gospodarczy sama siebie promuje i automatycznie obejmuje tym procesem kraj i region swej lokalizacji, jest więc samonapędzającym się mechanizmem nie tylko gospodarczym, ale i promocyjnym dla siebie i dla otoczenia, w którym funkcjonuje. Efekt ten jest szczególnie widoczny w sytuacji wyjściowo nieprzyjaznej dla kapitału obcego. Polska na przykład nadal stoi przed szeregiem wyzwań w odniesieniu do polityki przyciągania bezpośrednich inwestycji zagranicznych $^{19}$. Bariery - typu zbyt duży udział państwa w gospodarce, słaby rozwój infrastruktury transportowej i telekomunikacyjnej, niedopasowanie między kwalifikacjami siły roboczej, a rynkiem pracy i ogólnie brak zdecydowanej polityki kreowania przyjaznego środowiska dla prowadzeniu biznesu - niestety przekładają się też na stosunkowo niską efektywność promowania działalności tego typu.

17 www.paiz.gov.pl, stan z dnia 4.05.2012.

${ }_{18}$ W. Dziemianowicz, op. cit., s. 11.

${ }_{19}$ J. Błuszkowski, J. Garlicki, Opinia inwestorów zagranicznych o spotecznych i ekonomicznych warunkach dziatalności w Polsce, Raport z badania przeprowadzonego na zlecenie PAIZ przez Centrum Badań Marketingowych INDICATOR, Warszawa 2000. 


\section{ZAKOŃCZENIE}

Konsekwencją trwającego od początku lat 90. napływu do Polski zagranicznych inwestycji bezpośrednich jest systematyczny wzrost ich znaczenia gospodarczego w wymiarze ogólnokrajowym i regionalnym ${ }^{20} . Z$ obecnością zagranicznego kapitału produkcyjnego wiąże się szereg korzyści i oczekiwań, szczególnie $\mathrm{w}$ wymiarze regionalnym. Powstające i inwestujące w województwie podlaskim firmy z kapitałem zagranicznym tworzą dla tego regionu perspektywę rozwoju technologicznego i innowacyjności, dają środki finansowe budżetowi samorządowemu, wpływają regulująco na sferę zatrudnienia. Zrealizowane $\mathrm{w}$ formie inwestycji zagranicznych projekty stały się promocyjną wizytówką nie tylko siebie samych, ale i regionu, w którym się ulokowały. Wyznaczyły także kierunek wdrażania regionalnego programu atrakcyjności rynku podlaskiego i białostockiego w ramach aktywności proinwestycyjnej i promocyjnej władz samorządowych. Jego wyrazem jest tworzenie i dostosowywanie infrastruktury do kolejnych inwestorów, którzy już zauważyli potencjał i walory regionu oraz promocyjne pozyskiwanie kapitału zagranicznego, zarówno $\mathrm{w}$ wymiarze nieintencyjnym jak i poprzez celowe zabiegi nakłaniające.

\section{BIBLIOGRAFIA}

Błuszkowski J., Garlicki J., Opinia inwestorów zagranicznych o spotecznych i ekonomicznych warunkach dziatalności w Polsce, Raport z badania przeprowadzonego na zlecenie PAIZ przez Centrum Badań Marketingowych INDICATOR, Warszawa 2000.

Chrupek Z., Stan zagranicznych inwestycji bezpośrednich w Polsce, Warszawa 2002.

Czaputowicz J. (red.), Polityka zagraniczna Polski. Unia Europejska. Stany Zjednoczone. Sasiedzi, Warszawa 2008.

Dane statystyczne GUS.

Dziemianowicz W., Inwestycje zagraniczne jako czynnik rozwoju polskich regionórw, Warszawa 2002.

Garbarski L., Rutkowski J., Wrzosek W., Marketing punkt zwrotny nowoczesnej firmy, Warszawa 1996.

Godlewska-Majkowska H., Zarębski P., Atrakcyjność inwestycyjna regionów 2010. Województwo podlaskie, Warszawa 2010.

${ }^{20}$ J. Czaputowicz (red.), Polityka zagraniczna Polski. Unia Europejska. Stany Zjednoczone. Sasiedzi, Warszawa 2008, s. 89. 
Informacja o sytuacji na rynku pracy Powiatowego Urzędu Pracy w Biatymstoku w 2010 roku, Białystok 2011.

Liberda B., Inwestycje zagraniczne, oszczędności werwnętrzne i polityka gospodarcza, Warszawa 1999.

Lista największych inwestorów zagranicznych w Polsce - grudzien 2011 wg PAIiIZ S.A. Raport o stanie gospodarki - Polska 2010.

Sadowski Z., Kapitat zagraniczny w Polsce. Warunki dziatania, Warszawa 1999.

Stownik jezyka polskiego PWN, t. 3, Warszawa 1999.

Sytuacja spoteczno-gospodarcza Miasta Biatystok w latach 2007-2009 r., Urząd Statystyczny w Białymstoku.

Wiktor W. J., Promocja. System komunikacji przedsiębiorstwa z rynkiem, Warszawa 2001. Witkowska J., Ekspertyza dla Ministerstwa Rozwoju Regionalnego: Rola kapitatu zagranicznego w kreowaniu przewag konkurencyjnych polskiej gospodarki, Łódź 2009 r. www.bat.com.pl www.bialystok.gazeta.pl

www.kancelaria.lex.pl

www.paiz.gov.pl

www.podlaskie.strefabiznesu.pl

www.wspolczesna.pl

Zimbardo Ph.G., Psychologia i życie, Warszawa 1999. 
